\title{
The profound impacts of sodia-silica interactions in silicate melts
}

\author{
C.C. LUNDSTROM ${ }^{1}$
}

${ }^{1}$ Dept of Geology, University of Illinois Urbana-Champaign, Urbana, IL 61801, USA (lundstro@illinois.edu)

Work in Mac's lab in 1998 led to the finding that $\mathrm{Na}$ in an alkali basalt would rapidly diffuse into peridotite, cause incongruent breakdown of OPX and form an interstitial rhyolite-like melt in 10 minute long experiments [1]. Element profiles could be modeled by coupling $\mathrm{Na}$ diffusion to changes in melt silica content. The formation of the interstitial silicic melt is explained by the role of added alkalis on Ol-OPX saturated melts [2]. 20 years later, we can see a similar effect in the crust: a continuous change in melts saturated in quartz and albite exists from the eutectic down to extremely hydrous $\left(37 \mathrm{wt} \% \mathrm{H}_{2} \mathrm{O}\right)$ and sodic $\left(35 \% \mathrm{Na}_{2} \mathrm{O}\right.$ anhydrous) melt compositions at $330^{\circ} \mathrm{C}$ and $1 \mathrm{~kb}$ [3].

I will present new cold seal experiments in the $\mathrm{K}_{2} \mathrm{O}$ $\mathrm{Na}_{2} \mathrm{O}-\mathrm{Al}_{2} \mathrm{O}_{3}-\mathrm{SiO}_{2}-\mathrm{H}_{2} \mathrm{O}$ system showing that addition of orthoclase to the qtz-ab assemblage does little to change the oxide trends with decreasing temperature seen in [3]: $\mathrm{K}_{2} \mathrm{O}$, as well as $\mathrm{SiO}_{2}$ and $\mathrm{Al}_{2} \mathrm{O}_{3}$ decrease as $\mathrm{Na}_{2} \mathrm{O}$ (and $\mathrm{H}_{2} \mathrm{O}$ ) rises. Thus, as temperature falls, $\mathrm{Na}$ and $\mathrm{H}_{2} \mathrm{O}$ increasingly depolymerize the melt structure, perhaps illustrating the magmatic-hydrothermal transition. In the case of these crustal melts, it is $\mathrm{Na}$ that stabilizes monomeric silica in hydrous solution producing the melt compositional changes observed at $330^{\circ} \mathrm{C}$. An added observation from these experiments is that orthoclase crystals show dramatic replacements by albite. The result explains why andesite $+\mathrm{H}_{2} \mathrm{O}$ placed in a large thermal gradient leads to production of granite at $<400^{\circ} \mathrm{C}$ [4]: $\mathrm{Na}+\mathrm{H}_{2} \mathrm{O}$ diffuse into the low temperature region forming melt and allowing thermal migration to occur. Thus, granitic intrusions can retain $\mathrm{H}_{2} \mathrm{O}$-rich peralkaline melt down to temperatures as low as $330^{\circ} \mathrm{C}$.

Ultimately, both the OL-OPX and Qtz-feldspar melt behaviors illustrate the role of sodia-silica interactions in propagating melt connection into cold adjacent materials. A question in hindsight is whether water (and even carbonate) might also be playing an important role in the formation of silicic glasses in peridotite. Indeed, silica rich glasses found in mantle peridotites are often associated with newly formed amphibole and other water indicators. Speculatively, even plagiogranite veins of albite and qtz found in ophiolite peridotites reflects formation of this low temperature melt.

[1] Lundstrom, Nature 403:527 2000 [2] Kushiro, AJS 275:411, 1975 [3] Lundstrom, JGR 10.1029/2019JB017654. [4] Huang et al. GCA 73:729, 2009. 